\title{
ON THE REPRESENTATION OF THE CATEGORY OF NUMBER IN NOUNS IN ESTONIAN AND RUSSIAN DICTIONARIES
}

\author{
Irina Külmoja, Larisa Mukovskaya
}

\begin{abstract}
Perceiving the category of number as the subject of grammar only is an oversimplification. Number forms of nouns are very lexicalized, and their dictionary interpretation (especially singularia and pluralia tantum) is sometimes inconsistent. The analysis of contemporary dictionaries (mostly defining and explanatory) compiled in Estonia and Russia is a study on the interpretation of grammar in typological lexicography. The research examines the interpreting of number paradigm in nouns, difficulties of reflecting the availability of number forms in different semantic classes as well as the change in number paradigms with the formation of complex words. The analysis of dictionary entries brings to light the dependence of this representation on the national lexicographic traditions and dictionary types. Resolving the aforementioned inconsistency may be important as many contemporary dictionaries become the foundation for numerous software and online resources.*
\end{abstract}

Keywords: singularia tantum, pluralia tantum, lexicography, Estonian, Russian

\section{Introductory remarks}

The category of number in Estonian and Russian nouns is widely presented as an opposition of singular and plural forms. This singular/plural opposition in the system of Russian is considered obligatory for all declinable nouns (Švedova 1980: 469, Panova 2010: 90), and plural in this opposition is the marked form. Estonian grammar descriptions also tend to recognize the fact that each noun has its number form with singular appearing to be the unmarked form (EKK: 180, EKG I: 204, Tiits 1983: 356). However, not all nouns may be used in both singular and plural forms. Russian and Estonian distinguish singularia tantum (used only in singular)

* Part of this research was supported by the European Regional Development Fund (Archimedes Foundation, Dora 
and pluralia tantum (used only in plural) nouns. For linguists, many questions are triggered by the use of words with "empty" number paradigm valence in speech, e.g. is such a paradigm defective, is the marking of number on a noun obligatory or not, does a singular form always refer to a single referent and a plural form to multiple referents, and if a word without number marking is a word-form at all (Guzev 2020, 2016: 35-37)? Many of these questions remain unanswered despite the close attention that linguists pay to the category of number ${ }^{1}$ in nouns in many languages including some of the most well described ones.

Linguistic research (in our case, of Russian and Estonian) that aims to describe number in nouns and present a number paradigm looks, first of all, at the dictionaries of the languages in question. Grammar is by no means the goal of a dictionary but it should be present there in some way or other, and grammar marking is not always easy for the lexicographer (Viks 2000: 486, Langemets et al. 2005)². Existing handbooks of lexicography see no or little issue in describing the number properties of nouns accurately. We are going to look at this problem in more depth. Number forms of nouns are very lexicalized. It is the dictionary entry that, according to the researcher's expectations, should provide the information on number forms: does the word have a full number paradigm or is it used only in singular or plural forms? The entry's grammar field becomes the focus of a linguist expecting the dictionary's lexicographer to provide the answers. Information may be presented with the help of the following means:

1) there is a paradigm of forms, singular and plural forms given,

2) there is a grammar mark describing the noun's number paradigm (e.g. $p l$, sing. or $s g$.),

3) there is a "not used/rare" indication of some forms (singular or plural) or "singular/plural (only)" which is more common.

Information about noun forms may be explicit in a dictionary entry's headword. If, e.g., a noun is used only as plural, the headword is in plural, too, and the singular form is missing (either there is no singular form or it is possible but not used). The lack of Russian pluralia tantum words' singular forms in dictionaries (ножницы 'scissors', сани 'sledge') and their presence for some reason ${ }^{3}$ in dictionary entries in Estonian (EVS) can serve a good example:

(1) leetri|d $<p l$ l'eet·er ·ri ·ri[t -, -ri[te ·re[id $S$ o2 $>$ (EVS 2: 868) 'measles'

In Estonian, leetrid 'measles' is a plurale tantum noun. The dictionary, however, gives the singular form.

Examples of usage (pattern illustrations) from dictionary entries can provide information on nouns' number behaviour. Some set expressions, adverbial and bound verb phrases may become examples of such number behavior and stimulate the researcher to pay attention to the use of such forms and phrases in the text, recognizing the existing problems in description.

\footnotetext{
1 The category of number is the focus of numerous studies by linguists, cf. an extensive monograph by Corbett (2000) and its list of references.

2 Bo Svensen outlined the general principles of how grammar should be reflected in dictionaries; in particular, the inflectional information (Svensen 2009: 124-135, 143-157). The western lexicographic tradition of marking (un)countability, however, differs from that of Russia and Estonia, as will be shown below. Some dictionaries may follow such principles, as: "1. Inflectional information does not belong in dictionaries. This attitude was common

previously but has mostly been abandoned today. 2 . The users are expected to be familiar with the regular features of inflection; if they are not, they will have to consult a grammar [---]" (Svensen 2009: 125)

3 One of these reasons may be the ability of some pluralia tantum nouns to appear in singular in set expressions, constructions with nouns, locative cases and partial words. For more on this and Estonian examples see (Tiits 1983 358, 360-363); on partial words in lexicography see (Atkins, Rundell 2008: 180).
} 
The focus of our research is on how modern Russian and Estonian lexicography reflects the nouns' number forms in the grammar field of entries. The in-depth knowledge of this representation is crucial for linguists, i.e. expert users who incorporate vocabulary data into their own research, and other dictionary users. It is the vocabulary data that often forms the basic hypothesis and the basic data system thus preceding corpus-based research. Sometimes number marking is deceptively simple.

First of all, we are interested in how Estonian and Russian dictionaries reflect the following:

1) whether a noun has singular and plural forms used in speech,

2) whether a noun is plurale tantum,

3) whether a noun is singulare tantum,

4) preference in the use of singular or plural for some words (e.g., a rare/often mark).

Our aim is to find out if the means of lexicographic description providing the information on nouns' number behavior create a coherent system. Such a system, combined with the knowledge of grammar and vocabulary, allows for a clear picture of the number category in the language in question.

In the next section we give a brief overview of the presentation of number forms in Estonian and Russian dictionaries. In Section 3 we examine the strategies of number form marking, with further analysis and discussion in Section 4.

\section{Dictionaries and entries' grammar fields}

In this section we look at how various Estonian and Russian dictionaries render information on the use of words in singular and/or plural.

\subsection{Estonian dictionaries}

Singularia and pluralia tantum research in many languages mostly uses the database from defining dictionaries (for Russian, see, e.g., Lyaševskaja 2004: 12-13).

For Estonian, the most credible and only up to date academic defining print dictionary is the EKSS, first published in 2009 by the Institute of the Estonian Language. This dictionary is a second enlarged and improved edition of the Explanatory Dictionary of Written Estonian ("Eesti kirjakeele seletussõnaraamat”, EKSS), first published in twenty-six volumes in 1988-2007. EKSS contains around 150 ooo entries, and its online version is accessible at the Institute of the Estonian Language website. The paper version is an extensive six-volume publication.

In this dictionary, full paradigm nouns have an indication of their declination class in the grammar field of the dictionary entry, e.g., haru 'branch' is marked as class 11:

(2) haru 〈11〉 s (EKSS 1: 452) 'branch'

For words used only in singular the dictionary does not provide an indication that the word is listed as singularia tantum. E.g., headus 'kindness' lacks the sg. marking common to this dictionary: 
(3) headus <-e 5 v. -e 4> s. (EKSS 1: 460) 'kindness'

Approximately sixty nouns are defined as $s g$, $h r l s g$ (harilikult singular 'often singular') for one of their senses, e.g., argipäev '1. work day 2. everyday life'. The latter case is marked $s g$.:

(4) argi|päev 1. tööpäev [---] 2. (sg.) argielu [---] (EKSS 1: 135) ${ }^{4}$

Such marking of just some senses as singularia tantum most likely reflects a semantic shift for the word.

In the dictionary, pluralia tantum nouns are grammatically marked $p l$., their headword noun is plural, as in käärid 'scissors', lauakombed 'table etiquette rules', õekesed 'sisters', tunked 'overalls':

(5a) käärid pl., lauakombed pl., õekesed pl. ${ }^{5}$ (EKSS 1: 8)

(5b) tunked ‘6〉 s. pl (EKSS 1: 12, EKSS 5: 972)

For the nouns used only (or "often") in plural in one of their senses the pl. ( $h r l . p l$. mark is given only in relation to this sense and is bracketed. The headword is given in singular, as in krõps 'crisps' (kartulikrõpsud 'potato crisps'); emaema 'mothers's mom' (esiema 'foremother'):

(6a) krõps $1<-u$ 21〉 s. [---] 2. (hrl. pl.) KÕNEK kartulikrõpsud (EKSS 1: 12, EKSS 2: 518)

(6b) emaema ema poolt vanaema || (pl.) esiema (EKSS 1: 12)

Another defining dictionary is the PSV printed in 2004. The dictionary contains 5000 entries and is intended for the learners of Estonian (A2-B1 levels). The dictionary is also accessible at the Institute of the Estonian Language website. In this dictionary, nouns with a full paradigm have their forms of singular and plural (Est. mitmus) Nominative, Genitive and Partitive, e.g.:

(7) haru nimisõna < haru, haru, haru; mitmus harud, harude, harusid > (PSV: 74) 'branch'

If the word is used mainly (or "often") in singular, the plural forms are not given (PSV: 8):

(8) gripp nimisõna <gr `ipp, gripi, gr `ippi, gr `ippi> (PSV: 8, 69) 'flu'

The PSV uses the ainsuses 'in singular' mark which indicates that in one of its senses the noun is used in singular only, e.g.:

(9) kask nimisõna < ‘ ’as'k, kase, k`as'ke; mitmus kased, k`as'kede, k`as'ki> 1. puu, mille tüvel on valge koor [---]

2. (ainsuses) see puu materjalina (PSV: 124)

kask noun <k`as'k, kase, k`as'ke; plural kased, k`as'kede, k`as'ki>

1. the tree with white bark [---]

2. (singular) birchwood

For the words used only in singular the PSV online version provides a paradigm table with the singular forms only (see Table 1). 
Table 1. Plural forms of kurbus 'sorrow' missing. Source: PSV

\begin{tabular}{|l|l|c|}
\hline Case & \multicolumn{1}{|c|}{ Singular } & Plural \\
\hline Nominative & k'urbus & - \\
\hline Genitive & k'urbuse & - \\
\hline Partitive & k'urbust & - \\
\hline Illative, short form of & - & - \\
\hline Illative & k'urbusesse & - \\
\hline Inessive & k'urbuses & - \\
\hline Elative & k'urbusest & - \\
\hline Allative & k'urbusele & - \\
\hline Adessive & k'urbusel & - \\
\hline Ablative & k'urbuselt & - \\
\hline Translative & k'urbuseks & - \\
\hline Terminative & k'urbuseni & - \\
\hline Essive & k'urbusena & - \\
\hline Abessive & k'urbseta & - \\
\hline Comitative & k'urbusega & - \\
\hline
\end{tabular}

If a word is used only in plural, the grammar field will have the mitmus 'plural' mark and give only the plural forms:

(10) käärid mitmus nimisõna <käärid, k`ääride, k`ääre> (PSV: 8, 184) 'scissors'

The approach that EKSS authors take is fully compatible with that of the authors of the EVS, published in five volumes between 1997-2009 by the Institute of the Estonian Language. There is also an online version of the EVS (EVS 2019), which is in fact the second and enlarged release of the 1997-2009 printed text. While the EKSS grammar field provides reference to the declination class number (numerical code) (i.e., one can conclude that the declination paradigm has singular and plural forms including pluralia and singularia tantum), that of EVS shows all singular and plural forms for Nominative, Genitive and Partitive including singularia and pluralia tantum words, as in the singularia tantum words headus 'kindness' (11a) and agitatsioon 'agitation' (11b), and pluralia tantum or often used in plural words, e.g. $(12 a-12 b)$.

(11a) headus <h'eadus *e $\cdot[\mathrm{t} \cdot[\mathrm{se}, \cdot[\mathrm{te} \cdot / \mathrm{i} \& \cdot \mathrm{e}[\mathrm{id} S 11 \&$ og> (EVS 1: 634) 'kindness'

(11b) agitatsioon <agitatsi'oon ·ooni 'ooni =, 'ooni[de -'ooni[sid \& ·'oon/e $S$ 22> (EVS 1: 146) 'agitation'

(12a) drevljaanid $<p l$ drevlj'’aan ·aani •'aani =, '’aani[de ·'aani[sid \& ·'aan/e $S$ 22> (EVS 1: 13; 404) 'drevlians'

(12b)eel+võistlus $<h r l p l+$ v'õistlus · e $\cdot[\mathrm{t} \cdot[$ [se, $\cdot[$ te $\cdot / \mathrm{i} \& \cdot \mathrm{e}[\mathrm{id} S$ 11 \& o9> (EVS $1: 13$; 429) 'prelims, qualifying rounds'

According to the EVS, "the mark on the use of singular or plural serves a notifying rather than banning function and shows the preference or common nature in 
use of a form in question" (EVS I: 15, 33). However, there is only one grammatical commentary directly pointing at the singulare tantum use of a word in Estonian for almost one thousand pages of volume 1 :

(13) abielurahvas <sgt + rahvas r'ahva rahvas[t -, rahvas[te r'ahva[id $S$ o7> (EVS 1: 125) 'couple, spouses'

It is worth mentioning that in its translation section the EVS consistently marks the Russian equivalents used only in singular with a relevant mark. Cf. the translation options for Estonian kurbus: печаль 'sorrow', грусть 'sadness', скорбъ 'grief', горе 'woe' (14).

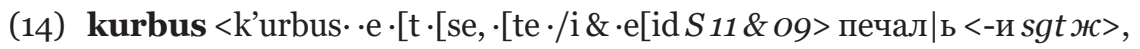
груст|ь <-и sgt ж>, скорб|ь <-и sgt ж>, горест|ь <-и sgt ж>, гор $\mid \mathrm{e}<-$ я sgt $c>$ (EVS 2: 602)

Consistent marking of singularia tantum nouns in the translation section is true for the active type dictionaries ${ }^{6}$ only and makes them a useful tool for the learner of Russian (the case of EVS). For more on the principles of presenting grammar information in active type dictionaries, see (Viks 2008: 250).

\subsection{Russian dictionaries}

Here we examine only the defining dictionaries of Russian that are comparable in volume with the EKSS, namely The Dictionary of the Russian Language («Словарь русского языка») in 4 volumes ed. by A. Yevgenyjeva, and the Big Russian Explanatory Dictionary («Большой толковый словарь русского языка», BRED), ed. by S. Kuznetsov. The former is often referred to as the Small Academic Dictionary («Малый академический словарь», MAS). The principles of reflecting nouns' number behaviour in these dictionaries fall in the long-established Russian tradition and are still in use (cf. the grammar features for different parts of speech in Russian dictionaries in (Švedova 2005: 422)).

MAS is a dictionary of standard Russian. Its first edition appeared in 1957-1961 and contained around 80 ooo entries; its second, updated version (1981-1984) and further releases are enlarged to around 90 ooo entries. Nouns with correlative (without a meaning shift) singular and plural forms are listed in singular; their Genitive form, functioning in Russian dictionaries similarly to the declination class number in Estonian dictionaries, is also provided. Nouns used only in singular do not possess specific indication, e.g.:

(15) БЕЛЬЁ, -я́, ср., собир. (MAS) 'linen; underwear’’

Pluralia tantum nouns are marked with the $\boldsymbol{м н}$. 'plural' mark, the headword is given in plural with an indication of their Genitive ending, e.g.:

(16a) СА́НИ, -éŭ, мн. (MAS)‘sledge’

(16b) ВЕСЫ', -о́в, мн. (MAS) 'scales'

Svensen (2009) calls them 'dictionaries for production'.

7 Cf. собир.'collective' in (15) with the English practice to tag COUNT and MASS nouns (Atkins, Rundell 2008: 221, 337,400 ) and use the PL code for indicating the syntactic agreement (e.g., see noun cattle marked PLURAL N example in English (Ibid.: 406)). 
Nouns that are used mainly in plural (but have a singular form, too) are also given in plural, their singular form in such cases is bracketed with the indication of their Genitive ending and gender, e.g., the entry for the lexeme лыжи 'ski', усы 'moustache':

(17а) ль́жи, льж, мн. (ед. лы́жа, -и, ж.)(MAS)

(17b) УС́́, -о́в, мн. (ед. ус, -а, м.) (MAS).

The first edition of BRED appeared in 1998 in St. Petersburg and contains around 130 ooo words. Nouns with no plural forms are listed without any specific indication of this morphological feature, e.g.:

(18а) ЖАЖДА, -ы; ж (BRED) 'thirst'

(18b) ОВОЩЕВОДСТВО, -a; cp. (BRED) 'vegetable growing'

Nouns with no singular forms are listed in plural (gender not indicated), e.g.:

(19a) ДРОЖЖИ, -ей; мн. (BRED) 'yeast'

(19b) САНИ, -ей; мн. (BRED) 'sledge'

Headwords for nouns used mainly in plural (types of shoes, some paired objects etc.) are given in plural and are marked with $\boldsymbol{м н}$. 'plural'. Singular forms are given in brackets with the indication of Genitive and gender, e.g.:

(20а) ЖАБРЫ, жабр; мн. (ед, жабра, -ы; ж.) (BRED) 'gills'

(20b) КОЗНИ, -ей; мн. (ед. кознь, -и; ж.) (BRED) 'intrigue'

Russian dictionaries use similar marks: $\mathbf{M H}$. 'plural' for pluralia tantum nouns (16a, 19a), ed. 'singular' to indicate the singular forms of nouns most commonly used in plural (е.g. САПОГИ́, -пóz, -ám, мн. (ед. сапо́г, -á, м.) (MAS) 'boots'). Estonian dictionaries use various grammar marks: $s g$. (4) / ainsuses (9)'in singular', sgt. for singularia tantum nouns (or senses) (13); and pl. (5a, 5b) / mitmus (10)'plural' for pluralia tantum nouns; $\mathrm{hrl} . p l$. 'often in plural' (6a, 12b), tavaliselt mitmuses 'often in plural' (e.g., närv [---] 2. (tavaliselt mitmuses) (PSV: 256) 'nerves') to indicate nouns commonly used in plural.

\section{Strategies of number form marking in dictionaries}

\subsection{Nouns with correlative singular and plural forms}

For all nouns with correlative singular and plural forms the headword is given in the singular form of Nominative. In Estonian dictionaries the entry's grammar field either indicates the noun's declination class (e.g., tegevus <-e 5〉 s (EKSS 5: 698) 'activity'; laud «laua 23> s (EKSS 3: 67) 'table') or lists the singular and plural forms of the three basic cases (e.g., mees <mehe, meest, mehesse, meeste, mehi, meestesse 35' s (EKSS 3: 377) 'man'). In Russian dictionaries such "full-paradigm" nouns are shown with the singular Genitive form and gender marking (e.g., СТОЛ ${ }^{1}$. -á, м. (MAS) 'table'). 


\subsection{Singularia and pluralia tantum nouns}

Linguists pay considerable attention to nouns with defective number paradigms where the missing singular or plural forms may be explained by systemic (semantic or functional) reasons and the nouns classified on semantic grounds.

When pluralia or singularia tantum nouns are included in a dictionary, the lexicographer inevitably faces the problem of their grammatical description, i.e. what information is needed in the grammar field of the entry. The strategies here may be influenced by the lexicographic tradition(s) and the lexicographer's professional approach.

It seems that it is the lexicographic tradition for both the Russian dictionaries and EVS to present the headwords for ethnic groups in plural (here we talk about the cases when plural is formed according to the regular rules from the singular form):

(21a) langobardid (EVS 2: 831) 'Langobards', sardid (EVS 4: 374) 'Sards', sardiinlased (EVS 4: 374) 'Sardinians', zaporoožlased (EVS 4: 830) 'Zaporozhye cossacks'

unlike the names of the ethnic groups where the singular form is not always available:

(21b) lõunaslaavlased (EVS 2: 1033) ‘south Slavonians', läänemeresoomlased (EVS 2: 1057) 'Baltic Finns', obiugrilased (EVS 3: 575) 'Ob-Ugrians', tšuudid (EVS 5: 129) 'Chudes'

BRED has 335 ethnic headwords in plural, e.g.:

(21c) белорусы 'Belorussians', эстонцы 'Estonians' японцы 'Japanese' (BRED; also in MAS)

Plural in the dictionary entry, even when this plural is regularly derived from the singular (e.g., Japanese - the Japanese), may be justified by the interpretation of the plural form as an aggregation with its own qualities rather than the arithmetic multitude (Japanese + Japanese + Japanese). EKSS explains this in the following way: "In some cases, e.g. in order to facilitate the definition of ethnic groups' individual members, the headword is supplemented by the plural which is defined" (EKSS 1: 10):

(21d) abhaas <-i 21〉 s., abhaasid pl. rahvas Kaukaasias (EKSS 1: 10) 'Abkhaz <-i 21〉 s., Abkhazians, a Caucasian people'

Nouns presented in plural (for the convenience of such presentation) in scientific classifications can be related to the lexicographic tradition to treat terminology; e.g.:

(22a) kaslased $<p l \mathrm{k}$ 'asla $\cdot \mathrm{ne} \cdot \mathrm{se} \cdot \mathrm{s}[\mathrm{t} \cdot \mathrm{s}[\mathrm{se}, \cdot \mathrm{s}[\mathrm{te} \cdot \mathrm{s} / \mathrm{i} \& \cdot \mathrm{se}[\mathrm{id} S 12 \& 10$ ? $>$ (EVS 2: 138) 'felines'

(22b) karelehelised $<p l+$ leheli.ne $\cdot \mathrm{se} \cdot \mathrm{s}[\mathrm{t} \cdot \mathrm{s}[\mathrm{se}, \cdot \mathrm{s}[\mathrm{te} \cdot \mathrm{s} / \mathrm{i} S$ 12> (EVS 2: 115) 'starflower'

Russian dictionaries do not mark the "technical" inability of some words to form plural, when a word's lack of “one or few forms due to phonological or morphological difficulties (for some occasional reasons) is not accounted for while relating 
the word to a certain grammatical class, e.g. no plural of мәла 'darkness', мзда 'bribe', хна 'henna' (Zaliznyak 1980: 5). Traditional grammars of Russian and Estonian treat the nouns that form only singular or plural as nouns with defective (incomplete) paradigms (Švedova 1980: 453, Zaliznyak 2002: 30, Panova 2010: 33-34, EKG I: 99). In Russian monolingual dictionaries singularia tantum words are listed without any specific grammatical commentary. The lexicographers share the position of A. Zaliznyak who defines it in the Grammatical Dictionary of Russian: 'The so-called singularia tantum, e.g. eда 'food', диета 'diet', нейтралитет 'neutrality', гордость 'pride', горение 'burning' etc. are believed to possess both numbers: plural is potential and almost never used, but, when necessary, it can still be formed and understood correctly" (Zaliznyak 1980: 5).

Grammar outlines that sometimes precede the dictionaries often contain paradigm tables. Thus, the VES has Russian paradigm tables (VES 1: 42-128). Unfortunately, these tables bear traces of either inattention at printing or the authors' unclear position (see Table 2; for details, see VES 1: 49):

Table 2. Missing SG forms of братья 'brothers', брусья 'bars', Әрузья 'friends' (VES 1: 49)

\begin{tabular}{|l|l|l|l|l|}
\hline Number & Case & \multicolumn{1}{|c|}{ Animate } & \multicolumn{1}{c|}{ Inanimate } & \multicolumn{1}{c|}{ Animate } \\
\hline \multirow{5}{*}{ Singular } & Nom & - & - & - \\
\cline { 2 - 5 } & Gen & - & - & - \\
\cline { 2 - 6 } & Dat & - & - & - \\
\cline { 2 - 6 } & Acc & - & - & - \\
\cline { 2 - 5 } & Inst & - & - & - \\
\cline { 2 - 5 } & Prep & - & - & - \\
\hline \multirow{5}{*}{ Plural } & Nom & бра́тья & бру́сья & друзья \\
\cline { 2 - 5 } & Gen & бра́тьев & бру́сьев & друзей \\
\cline { 2 - 5 } & Dat & бра́тьям & бру́сьям & друзьям \\
\cline { 2 - 5 } & Aсс & бра́тьев & бру́сья & друзей \\
\cline { 2 - 5 } & Inst & бра́тьями & бру́сьями & друзьями \\
\cline { 2 - 5 } & Prep & о бра́тьях & о бру́сьях & о друзьях \\
\hline
\end{tabular}

Bilingual and learners' dictionaries offer recommendations on the use of singularia tantum words, providing only their singular forms. This approach is shared by PVS and EVS for the Russian words.

Pluralia tantum words are always marked as plural or only plural. Even in the Grammatical Dictionary of Russian, Zaliznyak states his position in the following way: "In order not to hamper the readers with terminological novelties, such nouns are presented in this dictionary as close as possible to the traditional way, i.e. in the entry they are marked with $\mathcal{M H}$. (plural) instead of a gender mark; the declination tables list them as possessing only plural; in the grammar outlines they are referred to by the traditional pluralia tantum term" (Zaliznyak 1980: 5). The fact that a noun is only used as plural is also indicated by its plural headword.

Our analysis of the existing Estonian lexicographic sources makes it possible to assess the following "strategies" to introduce pluralia tantum nouns. A plurale tantum noun: 
1) is listed as a plural headword and has a grammar mark (23a);

(23a) liha_v`õtted mitm (ÕS 2018: 484) 'Easter’

2) is listed as a singular headword and has a grammar mark (23b, 23c);

(23b) liha|võte 〈hrl. pl.> (EKSS) 'Easter'

(23c) lihavõte $<h r l p l$ + võte v'õtte võte[t -, võte[te v’õtte[id $S$ o6> (EVS 2: 905) 'Easter'

3) is listed as a headword without grammar marks (23d, 23e).

(23d) neeruvoolme|d, -te (Tamm 1999: 319) 'renal colic'

(23e) jutu_märgid (ÕS 2018: 275) 'quotation marks'

We notice that strategies 1 and 3 quote examples from the same source.

There are nouns that, strictly speaking, cannot be considered "absolutely" defective. In the dictionaries they are marked $\mathrm{hrlpl}$, скорее/обычно мн./преимущ. мн. 'often plural':

(24a) jalats $<$ hrl pl jalats $\cdot \mathrm{i} \cdot \mathrm{i}[\mathrm{t}-, \cdot \mathrm{i}[\mathrm{te} \cdot \mathrm{e}[\mathrm{id} S$ o2 $>(\mathrm{EVS} 1: 856)$ 'shoe, footwear'

(24b) traks II < tr'aks traksi tr'aksi =, tr'aksi[de tr'aksi[sid \& tr'aks/e $S$ 22; hrl $p l>(E V S$ 5: 81) 'suspender'

In Russian, similarly to Estonian, they are, first of all, the nouns denoting paired objects: кегли 'skittles', подтяжки 'suspenders', вожжи 'reins'. We can also look at some nouns that do not denote paired objects and are not "absolutely" defective.

(25a) hiidlaine < hrl pl +laine l'aine laine[t -, laine[te l'aine[id $S$ o6 > (EVS 1: 657) 'tsunami'

(25b) ahju|puu < hrl pl +p'uu p'uu p'uu[d -, p'uu[de \& puu[de p'uu[sid \& p'u[id $S 26^{*}>$ (EVS 1: 152) 'firewood'

The dictionaries also reflect the process of word formation that affects the number category $^{8}$. To illustrate this, the dictionaries in many cases show a noun with a full paradigm of correlating singular and plural forms becoming part of a complex word (cited under a separate headword) and changing its number behavior. E.g., Estonian king 'shoe' has singular and plural while the complex word jooksukingad 'running shoes' is marked as plurale tantum:

(26a) king < k'ing kinga k'inga =, k'inga[de k'inga[sid \& k'ing/i $S$ 22> (EVS 2: 269) 'shoe'

(26b) jooksu + kingad $<p l+$ k'ing kinga k’inga =, k'inga[de k'inga[sid \& k'ing/i $S$ 22> (EVS 1: 877) 'running shoes'

A correlating example in Russian would be the complex words with the second component товары 'goods': канцтовары 'stationery', хозтовары 'household goods'; материалы 'materials': стройматериалы 'building materials'.

This seeming inconsistency in the ways to render the number behavior of nouns in dictionaries may be explained, at least to some extent, for singularia tantum words by the nouns' ability to rebuild their full morphological paradigm. Pluralia tantum words are listed in the dictionaries according to the general lexicographic 
tradition and the authors' methodology, most commonly in bilingual dictionaries. The grammatical status of pluralia tantum words decisively affects the way they are presented. This status is based on the theoretical interpretation of number as an inflexional or derivational category and the (non)acceptance of paradigmatic gaps, or "defective" paradigms.

\section{Conclusion}

Modern dictionaries in both Russian and Estonian lexicographic traditions try to mark the number behavior of nouns by reflecting it in the number forms of headwords and in the grammar field of the entries. However, as shown before, sometimes this marking is quite inconsistent. Learners' and bilingual dictionaries may be an exception, as their authors deliberately try to offer word descriptions that might be of use in the choice of a standard form and in the general study of language.

This inconsistency in the marking of number forms often follows from the complex nature of the language itself. For instance, in theory it may be related to an unsettled norm or change in the number behavior of certain nouns over the course of language and society development (Kostomarov 1994: 189-190, Gorbov 2014). For obvious reasons, dictionaries may not be fast enough to reflect all the changes the language is going through; electronic and online versions of the dictionaries, easily enlarged and updated, therefore gain new importance.

In some cases the dictionary marks mirror the problem of determining the paradigm itself (cf. example 4) or provide just the singular Partitive when it is possible to build a full paradigm, which seems to be the case of all Estonian nouns except for the borrowed calques like de jure, e.g. mahti:

(27) m mahti <ainult ains os> aega, võimalust [---] (ÕS 2018: 529) 'm`ahti $<$ only SG PART > time, ability'

We also assume that the cases when an element can be interpreted as a noun or part of a verbal form (for details, see Muischnek, Vider 2004) may cause complications for lexicographic description.

Other reasons for difficulties in determining a paradigm of commonly used forms may be their varying contextual use, the author's stylistic devices or the stems' derivational potential. This is characteristic of the words normally used in singular but always available for the potential building and use of plural, e.g.:

(28a) Tuleb arvestada ka iga konkreetse rahva minevikuga. (EKK: 194) 'One should also consider the past (past-SG) of every people in question.'

(28b) Ühise keele leidmiseks olid nende meeste minevikud olnud liiga erinevad. (EKK: 194) 'In order to find the common language, these men's past (past-PL) was too far from one another.'

For nouns most commonly used in plural, the use of singular is possible in some set expressions, e.g.:

(29a) Jõulud olid sel aastal ilma lumeta. (EKK: 194) 'Christmas (Christmas-PL) this year was without snow.'

(29b) Tule jõuluks koju. (EKK: 194) 'Come home for Christmas (Christmas-SG).’ 
Similar examples are also found in the example fields of dictionary entries. The aforesaid urges the lexicographer into the theoretical interpretation of number forms and their paradigmatic relations. This interpretation may prove not easy at all when attributing a word to a part of speech and may in the end yield to varying representation in dictionaries and computer processing algorithms.

The authors believe that a cohesive (uniform) approach to marking the number behavior of nouns should be extended to at least the whole lexicographic publication, and even further to the lexicographic tradition the dictionary belongs to. This appeal in modern times becomes almost a practical requirement as more various dictionaries appearing on top of the current lexicographic boom later become the foundation for large corpora and other electronic resources.

\section{References}

Atkins, B. T. Sue; Rundell, Michael 2008. The Oxford Guide to Practical Lexicography. Oxford University Press.

BRED = Bolšoj tolkovyj slovar' russkogo jazyka ['Big Explanatory Dictionary of Russian']. S.A. Kuznetsov (Ed.). Pervoje izdanije. St.Petersburg: Norint, 1998.

Bulatova, Lidija N. 1983. Ješčë o grammatičeskom statuse kategorii čisla suščestvitel'nyh v russkom jazyke ['More on the grammatical status of the category of number in Russian nouns']. - Problemy strukturnoj lingvistiki 1981. Moskva, 120-130.

Corbett, Greville G. 2000. Number. Cambridge University Press. https://doi.org/10.1017/ CBO9781139164344

EKG I = Erelt, Mati; Kasik, Reet; Metslang, Helle; Rajandi, Henno; Ross, Kristina; Saari, Hein; Tael, Kaja; Vare, Silvi 1995. Eesti keele grammatika 1. Morfoloogia. Sõnamoodustus ['Grammar of the Estonian Language 1. Morphology. Derivation']. Tallinn: Eesti Teaduste Akadeemia Eesti Keele Instituut.

EKK = Erelt, Mati; Erelt, Tiiu; Ross, Kristina 2007. Eesti keele käsiraamat ['Handbook of Estonian']. Kolmas, täiend. trükk. Tallinn: Eesti Keele Sihtasutus. https://www.eki. ee/books/ekkog/ (1.1.2020).

EKSS = Eesti kirjakeele seletussõnaraamat 1-7 ['Explanatory Dictionary of Literary Estonian']. Nurm, Ernst; Raiet, Erich; Karelson, Rudolf; Põlma, Valve; Kullus, Valve; Tiits, Mai; Valdre, Tiia; Veskis, Leidi (Toim.). Eesti Keele Instituut. Tallinn: Valgus, 1988-2007.

EKSS $=$ Eesti keele seletav sõnaraamat I-VI ['The Explanatory Dictionary of Estonian']. "Eesti kirjakeele seletussõnaraamatu” 2., täiendatud ja parandatud trükk. Margit Langemets, Mai Tiits, Tiia Valdre, Leidi Veskis, Ülle Viks, Piret Voll (Toim.). Eesti Keele Instituut. Tallinn: Eesti Keele Sihtasutus, 2009. http://www.eki.ee/dict/ekss (9.9.2019).

EVS = Eesti-vene sõnaraamat ['Estonian-Russian Dictionary']. Vol. 1. Romet, Anne; Liiv, Maimu (Vastutav toim.); Riikoja, Elli; Martoja, Inna; Smirnov, Savvati; Veskimägi, Enn (Toim.). Liiv, Maimu; Laasi, Helga; Lagle, Tiiu; Pärn, Hele; Leemets, Helle; Romet, Anne; Simm, Leeni; Viks, Ülle (Koost.). Tallinn: Eesti Keele Instituut, 1997; vol. 2. Romet, Anne (Vastutav toim.); Tiits, Mai; Tetsov, Mare (Toim.). Lagle, Tiiu; Liiv, Maimu; Romet, Anne; Viks, Ülle (Koost.). Tallinn: Eesti Keele Instituut, 2000; vol. 3. Romet, Anne; Melts, Nelli (Vastutav toim.); Valdre, Tiia (Toim.). Lagle, Tiiu; Liiv, Maimu; Kallas, Jelena; Romet, Anne; Viks, Ülle (Koost.). Tallinn: Eesti Keele Instituut, 2003; vol. 4. Melts, Nelli (Vastutav toim.); Valdre, Tiia (Toim.). Kallas, Jelena; Laasi, Helga; Lagle, Tiiu; Liiv, Maimu; Viks, Ülle (Koost.). Tallinn: Eesti Keele Instituut, 2006; vol. 5. Melts, Nelli (Vastutav toim.); Valdre, Tiia (Toim.). Laasi, Helga; Lagle, Tiiu; Liiv, Maimu; Viks, Ülle (Koost.). Tallinn: Eesti Keele Instituut, 2009. http:// www.eki.ee/dict/evs1997 (9.9.2019). 
EVS 2019 = Eesti-vene sõnaraamat 2019 ['Estonian-Russian Dictionary']. 2., täiendatud ja kohandatud veebiväljaanne. Kallas, Jelena; Melts, Nelli (Uute sõnade osa toim.). Kotova, Nelli; Melts, Maia; Matt, Kristina; Tubin, Valentina (Uute sõnade osa koost.). http://www.eki.ee/dict/evs (9.9.2019).

Gorbov, Andrei A. 2014. Čislovyje paradigmy abstraktnyh suščestvitel'nyh v russkom jazyke $\mathrm{XX}$ veka: tendentsii razvitija i vlijanija anglijskogo jazyka ['Number paradigms of abstract nouns in twentieth-century Russian: Development trends and the influence of English']. - Russian Linguistics, 38 (1), 23-46. https://doi.org/10.1007/ s11185-013-9120-Z

Guzev, Viktor G. 2016. O nekotoryh somnitelnyh predstavlenijah v oblasti tjurkskoj grammatiki ['On some doubtful ideas in the field of Turkic grammar']. - Aktualnyje voprosy tjurkologičeskih issledovanij ['Actual Problems of Turkic Studies']. St.Petersburg, $34-45$.

Guzev, Viktor G. 2020. O tjurkskih leksičeskih jedinitsah bez grammaticčeskogo oformlenija ['On Turcic lexemes without grammatical form']. In print.

Kostomarov, Vitali G. 1994. Jazykovoj vkus epohi: Iz nabljudenij nad rečevoj praktikoj mass-media ['Language taste of an epoch: The observation of media speech practice']. Moscow: Pedagogika-Press.

Langemets, Margit; Mägedi, Merike; Viks, Ülle 2005. Süntaktiline info sõnastikus: probleeme ja väljavaateid ['Syntactic information in a dictionary: Problems and perspectives'] - Eesti Rakenduslingvistika Ühingu aastaraamat, 1, 71-98. https://doi.org/10.5128/ ERYa1.04

Lyaševskaja, Olga N. 2004. Semantika russkogo čisla ['Russian Number Semantics']. Moscow: Jazyki slavyanskoj kul'tury.

MAS = Slovar' russkogo jazyka 1-4 ['Dictionary of the Russian Language']. A. P. Jevgenyjeva (Ed.). SSSR, Institut russkogo jazyka. 4-e izd., stereotip. Moscow: Russkij jazyk, 1999. http://feb-web.ru/feb/mas/mas-abc/oencyc.htm (9.9.2019).

Melčuk, Igor A. 1998. Slovoizmenitel'nyje kategorii, vyražajuščie količestvo ['Inflectional categories expressing quantity']. - I. A. Melčuk, Kurs obsčej morfologii. T. II, č. 2., gl. II-3. Moscow-Vienna, 82-98.

Muischnek, Kadri; Vider, Kadri 2004. Sõnaliigituse kitsakohad eesti keele arvutianalüüsis ['The problems of word class disambiguation in the automatic analysis of Estonian']. Eesti Rakenduslingvistika Ühingu aastaraamat, 1, 99-114. https://doi.org/10.5128/ ERYa1.05

Panova, Galina I. 2010. Morfologija russkogo jazyka. Èntsiklopedičeskij slovar'-spravočnik ['Morphology of the Russian Language. The Encyclopedia']. Moscow: URSS.

PSV = Eesti keele põhisõnavara sõnastik ['Basic Estonian Dictionary']. Kallas, Jelena; Tiits, Mai; Tuulik, Maria (Toim.). Jürviste, Madis; Koppel, Kristina; Tuulik, Maria (Koost.). Tallinn: Eesti Keele Sihtasutus, 2004. https://www.eki.ee/dict/psv (9.9.2019).

Soboleva, Polina A. 1979. Množestvennoje slovoizmenitel'noje i množestvennoje slovoobrazovatel'noje: ierarhija značenij ['Inflectional plural and derivational plural: A hierarchy of meanings']. - Perevodnaja i učebnaja leksikografija. Moskva, 52-76.

Svensen, Bo 2009. A Handbook of Lexicography: The Theory and Practice of Dictionarymaking. New York: Cambridge University Press.

Švedova, Natalia J. (Ed.) 1980. Russkaja Grammatika. Vol. 1. Fonetika. Fonologija. Udarenije. Intonacija. Slovoobrazovanije. Morfologija ['Russian Grammar. Vol. 1: Phonetics. Phonology. Stress. Intonation. Derivation. Morphology']. Moskva: Nauka.

Švedova, Natalia J. 2005. Paradoksy slovarnoj stat'i ['The paradoxes of a dictionary entry']. Russkij jazyk: Izbrannyje raboty ['Russian language: Selected papers']. Moskva: Jazyki slavyanskoj kul'tury, 420-424. 
Zaliznyak, Andrei A. 1980. Grammatičeskij slovar' russkogo jazyka. Slovoizmenenije. ['Grammatical dictionary of the Russian language. Inflection']. Izdanije vtoroje stereotipnoje. Moskva: Russkij jazyk.

Zaliznyak, Andrei A. 2002. "Russkoje slovoizmenenije" s priloženijem izbrannyh rabot po sovremennomu russkomu jazyku i obščemu jazykoznaniju ['The inflection in Russian with selected works on modern Russian language and general linguistics']. Moskva: Jazyki slavyanskoi kul'tury.

Tamm, Johan 1999. Eesti-vene sõnaraamat ['Estonian-Russian Dictionary]. 9., parandatud trükk. Tallinn: Valgus.

Tiits, Mai 1983. Lüngad eesti noomenivormistikus ['Gaps in Estonian noun forms']. - Keel ja Kirjandus, 7, 356-364.

VES = Vene-eesti sõnaraamat 1-2 ['Russian-Estonian Dictionary']. 2., parandatud trükk. Leemets, Helle; Saari, Henn; Kull, Rein; Erelt, Tiiu; Õim, Asta (Toim.). Erelt, Tiiu; Kull, Rein; Lagle, Tiiu; Leemets, Helle; Liiv, Maimu; Martoja, Inna; Mändmets, Hilja; Pärn, Hele; Riikoja, Elli; Romet, Anne; Saari, Henn; Simm, Leeni; Smirnov, Savvati; Vaigla, Eda; Veskimägi, Enn; Õim, Asta (Koost.). Tallinn: Eesti Keele Sihtasutus, 2000. http://www.eki.ee/dict/ves/index.cgi?Co6=en (9.9.2019).

Viks, Ülle 2000. Kuidas tekib sõnastikukirjesse grammatika ['A generator of grammatical entries for dictionaries']. - Keel ja Kirjandus, 7, 486-495. http://www.eki.ee/teemad/ kirjegeneraator.html (23.9.2019).

Viks, Ülle 2008. Eesti-x-keele sõnastik ja grammatika ['Estonian-X dictionary and grammar']. - Eesti Rakenduslingvistika Ühingu aastaraamat, 4, 247-261. https://doi. org/10.5128/ERYa4.15

ÕS 2018 = Eesti õigekeelsussõnaraamat ['Dictionary of Standard Estonian']. Raadik, Maire (Toim.). Erelt, Tiiu; Leemets, Tiina; Mäearu, Sirje; Raadik, Maire (Koost.). Tallinn: Eesti Keele Sihtasutus. https://www.eki.ee/dict/qs (1.1.2020). 


\title{
NIMISÕNA ARVUKATEGOORIAST EESTI JA VENE LEKSIKOGRAAFIAS
}

\author{
Irina Külmoja ${ }^{1}$, Larisa Mukovskaya ${ }^{1,2}$ \\ Tartu Ülikool', Peterburi Riiklik Ülikool ${ }^{2}$
}

\begin{abstract}
Nimisõna arvukategooria on laiem kui pelgalt grammatika nähtus. Nimisõna arvuvorme iseloomustab tugev leksikaliseerumine, mistõttu on sõnaraamatutes esitatav info selle sõnaliigi arvuvormide olemasolust ja moodustamise võimalustest sageli ebapiisav või ebajärjekindel. Eriti puudutab see plurale ja singulare tantum -sõnu. Autorid on analüüsinud tänapäeval Eestis ja Venemaal ilmunud (eelkõige seletavates) sõnaraamatutes esitatud grammatilisi andmeid tüpoloogilise leksikograafia aspektist. Käsitletakse nimisõna arvuparadigma interpreteerimise probleeme, eri tähendusrühmadesse kuuluvate nimisõnade arvuvormide esitamisraskusi märksõnaartiklis, arvuparadigma muutumist liitsõnade moodustamisel. Sõnaraamatute analüüsist ilmneb nii rahvusliku leksikograafia traditsiooni kui ka sõnaraamatu tüübi mõju nimisõna arvuvormide esitamisele. Samas läheb leksikograafiaallikate suurema ühtsuse saavutamine seoses digihumanitaaria arenguga järjest olulisemaks.
\end{abstract}

Võtmesõnad: singularia tantum, pluralia tantum, leksikograafia, eesti keel, vene keel

Irina Külmoja's (University of Tartu) research interests cover the areas of Russian functional grammar, contrastive grammar of Estonian and Russian, typology of Estonian, language contacts, Russian language in Estonia, and the language and culture of Russian Old Believers in Estonia. Lossi 3-226, 50090 Tartu, Estonia

irina.kulmoja@ut.ee

Larisa Mukovskaya (University of Tartu, St. Petersburg University) researches Estonian-Russian contrastive grammar, general linguistics, typology and lexicography. Lossi 3-226, 50090 Tartu, Estonia

larissa mukovsky@yahoo.com 